\title{
HRM IN FOREIGN-OWNED AGRICULTURAL AND FOOD PROCESSING COMPANIES IN SERBIA
}

\author{
Tatjana Ratković ${ }^{1}$
}

\begin{abstract}
Summary
This paper was aimed at analysing the degree to which foreign-owned agricultural and food processing companies in Serbia implement key human resource management (HRM) processes, determining whether these processes are performed in-house or outsourced, and identifying the variables which influence the decision on performing these processes within the company or outsourcing. The analysis of data collected through a survey conducted in 42 companies has confirmed the expectations that the surveyed companies mainly perform most of HRM activities The conclusion drawn from the study is that all examined HRM activities are mainly performed in-house, rather than outsourced, while the mode of performing key HRM processes mainly depends on the size of the company and the number of employees in HR department, implying that foreign-owned companies operating in agricultural and food processing sector in this transition country need to take these variables into consideration when deciding whether to perform crucial HRM activities by themselves or outsource.
\end{abstract}

Key words: human resource management, agriculture, food processing, recruitment, performance appraisal.

JEL: M510, Q13, L660

\section{Introduction}

Traditionally the role of HRM function has been weak in Serbian companies. It was usually focused on administrative issues, and often performed by a legal department. Multinational companies entered Serbian market relatively late, having in mind that this country has been cut off from other countries during the last decades. Having in mind that modern human resource management functions were brought to this country by multinational companies, it is not surprising that first modern HR departments were founded recently- since 2004/2005 (Cromer, 2008). HRM in Serbia has gone through significant changes during the last decade. Acquisition of local companies by overseas investors (especially multinational companies), restructuring of companies, introduction of contemporary technologies have

1 Tatjana Ratković, Ph.D., Teaching Assistant, Faculty of Organizational Sciences, University of Belgrade, Jove Ilica Street no. 154, 11000 Belgrade, Serbia, Phone: +381 113950 898, E-mail: tatjana.ratkovic@fon.bg.ac.rs

EP 2015 (62) 2 (353-367) 
all contributed to the development of HRM function in Serbian companies (Svetlik et al., 2010). This enabled Serbia to accomplish technology transfer that would help modernize its backward industry. The traditional concept of personnel management slowly started to move towards modern HRM concept applied in modern companies originating from developed countries. The companies slowly began to change the name, role and activities of "personnel management" to "human resource management" department. The aim of this research was to explore the HRM function in agricultural and food processing sector. According to Mihailović and associates (2013) agriculture in Serbia is limited by certain determinants- it adapts slowly to market business criteria which are based on introduction and implementation of modern management systems. The same may be claimed for food processing industry, which also lacks contemporary management systems, especially in terms of HRM.

\section{Agricultural and food processing sector in Serbia}

Agriculture and food processing represent one of the most significant economic sectors in Serbia. Having in mind available natural and human resources invested in this sector, it extensively contributes both to social and economic development of the country. It is one of dominating economic sectors due to the number of employees it provides employment for. Serbian agricultural and food industry, encompassing agricultural production and food and beverage processing, employs 557,000 people and accounts for around 16,6\% of national gross domestic product (GDP). However, if total contribution of agro-food industry to other economic sectors (particularly producers and processors of inputs and raw materials) is considered- this share accounts for more than $40 \%$ of total GDP. Convenient geographical position of the country, its climate, as well as high-quality soil contributes to positive results achieved in this sector (Vapa Tankosic, Stojsavljevic, 2012).

Over the past few years employment in agriculture has been falling down. However, it has still remained high. In 2013, approximately $21.3 \%$ of Serbian workforce (429,000 people) was employed in agriculture, which is among the highest percentages in European countries. A possible explanation for this may be a high percentage of seasonal and temporary workers employed in this sector.

There have been insufficient investments in agricultural sector in Serbia, which is one of the main reasons for lack of modernization of equipment and machines in agricultural companies. Even though there are three types of operations that may be found in this sector- including large agricultural companies, small family farming and commercial family farming (Bugar, Papic Blagojevic, 2009), the agricultural sector in Serbia is still mostly comprised of family/owneroperated and small businesses. Compared to other economic sectors, agriculture has a high percentage of unqualified workforce (Berde, 2006), with relatively low level of motivation among agricultural employees (primarily due to unattractive compensation packages).

Food processing represents the largest developmental opportunity for Serbia due to high natural potential, low labour costs and available land and water resources (Grozdanić, 2013). Food industry in Serbia represents more than $30 \%$ of total processing industry in the country. 
It is one of few economic sectors with positive foreign trade balance. Food industry currently employs approximately 65,000 employees, or $4.1 \%$ of total workforce in Serbia, which represents $20 \%$ of total number of employees in processing industry. During the last years, employment has been slightly increasing in this sector.

There are more than 4,500 businesses (SMEs and large companies) in the food processing industry operating in Serbia. These companies are predominantly small ones, $75 \%$ of food processing companies employ less than ten employees. There is a limited number of large, modern companies, which employ more than 250 employees (many of them represent subsidiaries of multinational companies); they are mainly found in grain processing, sugar industry, beverage (i.e. beer) industry.

There were many foreign direct investments in food processing industry during the last decade. This sector has passed through a huge privatization- more than $90 \%$ of companies operating in this sector are now owned by foreign companies. The total amount of foreign investments in agricultural and food processing sector since 2000 exceeded USD 1 billion. Foreign companies entered Serbian market mainly through acquisition and Greenfield investments, particularly in beverage, sugar, milk, meat industry (Ministry of Agriculture, Forestry and Water Management of the Republic of Serbia, 2014). Privatized companies brought capital, managerial skills, technical and technological innovations, they renovated and modernized plants and machines, which resulted in high-quality modern equipment and highly educated employees in most foreign-owned food processing companies. Most investments have been put in oil, beer, milk and confectionary industry; on the other hand sugar, meat, fruit and vegetables industry are characterized by less investments and technological modernization (Mihailović et al., 2013).

\section{Significance of HRM in agriculture and food processing sector}

Human resource management plays an important role in agriculture and food processing sector and represents one of the most complex issues in agro-food companies, being influenced more by social than economic determinants (Siva Rama Krishna et al., 1995). The expansion of agricultural and food processing industry has been viewed as one of the most significant sources of economic growth in agro-food sector in developing countries, while the most significant contribution to the success of every agro-food organization has been the productivity of its employees. Today it is commonly accepted that HRM has a significant influence on overall success of agricultural (Contò et al., 2012) and food processing companies.

The overall objective of every successful organization is to achieve sustained competitive advantage in a long-term. According to resource-based view, human resources may be a source of competitive advantage of a company, as companies may create economic value through utilization of their employees (Barney, 1991), only if their knowledge, skills and abilities can be used appropriately (Brewster et al., 2007). Beside other resources, human resources are often seen as a crucial strategic resource used by companies to achieve this objective, especially in agricultural and food processing sector (Mugera, 2012; Wilk, 
Fensterseifer, 2003). Having in mind that their people are their most valuable asset, agro-food companies and their managers need to search for the best ways to manage their employees effectively with an objective to achieve and maintain the desired market position (Mugera, 2010).

The role of human resource management in agro-food sector- where production, processing, and timely delivery of high-quality products depend on skills, knowledge and abilities of their employees- are of crucial importance. It is primarily aimed at recruiting, managing and maintaining the staff composed of highly specialized experts, semi-skilled workers and unskilled workers.

However, there is a lack of research regarding HRM in this sector as literature has paid insufficient attention to this topic (Bitsch, 2009). Research in HRM is usually focused on other sectors rather than agriculture and food processing. Additionally, it may happen that certain HRM practices developed for large companies cannot always be successfully implemented in smaller companies; also, practices defined for companies from other sectors may not work well in agricultural and food sector (Bitsch, 2009; Venclová et al., 2013). Having this in mind agricultural (as well as food processing) managers often have little evidence to rely on when developing HRM policies and procedures for their companies. This makes HRM processes in these companies much more complex, as managers need to develop specific systems for managing the workers efficiently and effectively. This explains the importance of HRM role in agro-food organizations (particularly multinational ones, which face much more complex issues in managing their employees).

Having in mind that main challenges faced by agro-food companies include attracting, motivating, and retaining qualified employees (Mugera, 2010), their HR departments should deal with different activities in order to satisfy and synchronize both individual and organizational goals. It should be ensured that each employee strives to achieve his/her goals which have derived from organizational objectives.

Since modern HRM concept was brought to Serbia relatively recently, and most often by foreign-owned companies, it was assumed in this research that mainly the subsidiaries of these companies in Serbia have implemented modern HR processes, rather than local companies. This is the reason why this survey focused only on foreign-owned companies in agricultural and food processing sector in Serbia (with many of them being subsidiaries of foreign multinational companies) in order to examine the following hypothesis:

Hypothesis 1: Foreign-owned agricultural and food processing companies in Serbia perform key HRM activities.

The following HRM activities were examined in this paper. Human resource planning refers to a process aimed at analysing and predicting organizational needs for human resources and their availability. Since success of companies involved in agricultural and food processing industry greatly depends on skills and experience of their human resources specialists, the objective of this process is to identify the number and the types of employees needed by an organization in the future to fill in its vacancies, as well as 
changes the organization should undertake in order to accomplish its goals - in terms of reducing the number of employees, training existing employees or hiring new personnel. In order to achieve expansion in agro-food organizations, HR departments need to perform appropriate personnel planning in all departments. HR department should work together with line managers in order to predict future organizational HR needs (both short-term and long-term) and determine the number and qualifications of specialized workers the organization will require depending on identified needs. It is the duty of HR department to ensure that these requirements are met in order to support crucial agricultural or food processing processes in the company.

When specific HR plans (short-term and long-term) have been made a company may start with recruitment- the process in which organization looks for candidates for potential employment. Therefore, this process refers to identification and attracting potential job candidates in order to satisfy current and future organizational HR needs. The aim is to obtain the necessary number and quality of employees in order to accomplish organizational HR needs. A key challenge agricultural and food processing companies must face in attempt to become and remain competitive refers to deciding on the ways of attracting and retaining skilled workforce (Morgan et al., 2004). Companies in agrofood sector employ different types of workers- mainly seasonal and contract workers (including harvest labour), technicians, but also supervisors and managers and thus require a wide dispersion of skills levels- from unskilled and low-skilled to high-skilled jobs. For example, Noel and Qenani (2013) found that skills such as creativity and critical thinking today become more important in agricultural sector. Having this in mind, skills and labour shortages may be a serious issue in this sector causing difficulties in recruiting adequate candidates. Besides, one of main problems faced by agricultural companies (both globally and in Serbia) refers to ageing workforce within agriculture as well as their education level (Ministry of Agriculture, Forestry and Water Management of the Republic of Serbia, 2014). Another challenge which may be faced refers to too many job candidates in agricultural sector, having in mind that the only option for most inhabitants in rural areas is to work in this sector (Siva Rama Krishna et al., 1995). Having in mind the specific nature of the business as well as knowledge, skills and abilities required, HR department should cooperate with department managers in the process of recruitment of agricultural and food processing employees.

Selection is often considered one of the most important HR processes in agro-food companies. It refers to the process in which an organization attempts to choose (among potential candidates identified in the previous phase) the ones who possess knowledge, skills, abilities and other characteristics required for accomplishment of organizational goals. Having in mind high cost of potential selection error, a lot of attention has to be paid to performing this process appropriately. So, companies should work hard to determine specific selection methods, techniques and procedures to ensure that the right person is selected for each vacancy as well as to ensure that particular agro-food business is fully staffed at all times with the most qualified people. 
As integral part of the process of human resources performance management, employee performance appraisal is one of the most important human resource management tools (Dessler, 2011). It refers to a process which enables a company to evaluate performance of its employees within a particular period of time based on previously clearly defined goals and targets. This process should ensure that each employee understands better his/her role in the organizations as well as his/her tasks, individual strengths and weaknesses related to his/her expected roles and functions in the company and it should increase and improve communication between an employee and HR department and managers.

Companies provide training programs for their employees to enable them to gain specific knowledge and skills necessary for performing their jobs effectively. HR department should pay significant attention to these issues. Whenever it is noticed that an employee lacks specific skills or knowledge training programs should be arranged - within the company or in other organizations, universities or institutes; employees may be sent to different seminars, conferences or workshops in order to gain necessary knowledge and become familiar with the best practices which they may later implement properly in the organization. In agriculture and food processing companies training represents one of the most significant responsibilities at all organizational levels. Employees (especially low-skilled workers) need to be trained to use agricultural machines or perform risky processes in food production or processing, particularly when a new technology has been introduced (Baptista, 2012). Safety trainings represent a priority for human resource management, in order to eliminate or reduce the possibility for injuries in the workplace or even death caused by inadequate handling with equipment and machines, or work-related illnesses.

HRM activities may be performed within the company or outsourced. There are many reasons for outsourcing these activities: it may be too complex for companies to deal with all HRM activities themselves; companies may reduce costs of HRM (of employing highly trained and experienced HR employees as well as necessary office space); they may improve the quality of HRM processes (services provided by HR agencies are professional as they are specialized only for particular HRM processes). Outsourcing may be a good solution for companies which don't have enough experience in HRM (e.g. when entering a new market). However, from a long-term perspective companies often prefer to establish their own HRM departments, rather than engage HR agencies for performing their crucial HRM activities.

The literature has identified various factors which are expected to have an influence on the decision to perform HRM processes within the company or outsource. Thus the following hypotheses were defined and later examined for five different HRM activates: HR planning, recruitment, selection, and training as well as performance appraisal of employees.

Hypothesis 2: The decision on performing key HRM activities themselves or outsourcing them depends on country of origin of the company.

Hypothesis 3: The decision on performing key HRM activities themselves or outsourcing them depends on company size.

Hypothesis 4: The decision on performing key HRM activities themselves or outsourcing 
them depends on company age.

Hypothesis 5: The decision on performing key HRM activities themselves or outsourcing them depends on the size of HR department.

\section{Methodology}

Data for the empirical research were derived from a questionnaire survey; the questionnaire was distributed to either HR manager or General Manager of each company. In general, literature lacks research dealing with HRM in agriculture and food processing industry. Another limitation of this study was a relatively low number of foreign-owned companies operating in agricultural and food-processing sector in Serbia. Having this in mind, companies for the research were selected regardless of their mode of founding, ownership type, size or age.

The questionnaire was developed after comprehensive review of relevant literature referring to HRM in agricultural and food processing sector. The questions were focused on different HRM activities performed in foreign-owned companies in Serbia. The aim of the research was: to discover the extent to which foreign-owned agricultural and food processing companies in Serbia implement key HRM activities and whether these activities are performed by themselves or outsourced, and to identify the variables which influence the decision on performing HRM activities within the company or outsourcing. In order to examine various aspects of HRM function in surveyed companies the research focused on the following HRM activities: planning, recruitment, selection, training, and performance appraisal. Independent variables examined within the study included the following: nationality (country of origin of the foreign-owned company), subsidiary size and age, as well as existence of HR department (number of employees in this department).

\section{Sample}

Total number of foreign-owned agricultural and food processing companies included in the research was 42. However, unlike food processing companies, agricultural sector in this country predominantly includes small (mainly local) companies and small familyowned farms, and employs a high percentage of unqualified workforces (compared to other economic sectors). Thus, companies covered by this research are mainly involved in food processing rather than agriculture: the majority of respondent companies (30 out of 42) in Serbia operate in the food processing sector, while only 12 companies are involved in agriculture. Almost half (45.2\%) of surveyed companies are involved in production of beverages (16.7\%), confectionary and snacks (14.3\%) and milk and dairy products (14.3\%). Other companies mainly produce agrochemicals and/or seeds, animal feed, as well as fruit and vegetables, sugar, products of grain processing (flour, cereals), meat, vegetable oil, frozen food products.

Foreign-owned agricultural and food processing companies in Serbia originate from 16 different countries. They primarily come from the USA $(16.7 \%)$, Netherlands $(16.7 \%)$ and France $(11.9 \%$ ), while almost $80 \%$ of them have their headquarters in European countries. 
Majority ( $88 \%$ ) of respondent agricultural and food processing companies in Serbia were founded in the last 15 years (26.2\% during the last 5 years, 31\% 6-10 years ago, 31\% 11-15 years ago), while only $11.9 \%$ of them exist in Serbia for more than 15 years.

Based on analysis of data it may be noticed that small foreign-owned agricultural and food processing organizations (with up to 50 employees) represent $23.8 \%$ of the sample, mediumsized companies (between 51 and 249 employees) account for $33.3 \%$, while large organizations (more than 250 employees) represent the majority of the sample- 42.9\%. The majority of large companies have more than 500 employees (66.7\%). The relatively high percentage of large companies in the sample may be explained by the fact that all surveyed companies are foreign-owned, and mainly represent subsidiaries of large foreign multinational companies (unlike local agricultural and food processing companies in Serbia which are mainly small).

The majority (77.8\%) of large companies surveyed was founded more than 5 and less than 15 years ago, while only 2 (out of 18) companies were founded during the last 5 years. Large foreign-owned agro-food companies in Serbia mainly operate in beverage industry (6 companies out of 18 , i.e. $33.3 \%$ of all large companies), confectionary and snacks $(22.2 \%)$ and milk and dairy products (16.7\%).

Regarding HR department, the analysis of the data has shown that there is a high number (28.6\%) of foreign agro-food companies in Serbia which do not have HR staff or HR department at all. Majority of companies (71.4\%) has some kind of HR department: 12 companies (28.6\%) have one employee in charge of HR processes, 13 companies (31\%) employ between 2 and 5 people in their HR department, while only 5 companies have more than five employees responsible for HR-related tasks (Table 1).

Table 1. Size of HR department

\begin{tabular}{|c|c|c|}
\hline No. of employees in HR department & No. of companies & $\mathbf{\%}$ \\
\hline 0 & 12 & 28,6 \\
\hline 1 & 12 & 28,6 \\
\hline 2 & 13 & 31 \\
\hline more than 5 & 5 & 11,9 \\
\hline Total & 42 & 100 \\
\hline
\end{tabular}

Source: According to data from Ratković, 2014.

It is usually suggested in the literature and practice that a company which employs 75 to 100 full time employees should consider employing at least one person responsible only for HR-related matters (human resource manager), (Barnard et al., 2012). Research has shown that existence of HR function highly depends on the size of the company- where smaller subsidiaries usually don't have HR departments or HR managers. Having in mind that smaller companies (usually with less than 50 employees) cannot afford to employ one person in charge of HR activities, crucial HR activities in such companies are usually performed and controlled by general manager or the owner, and other HR related activities may be delegated to other managers depending on their nature. Larger companies usually have a separate HR department. This research confirms this assumption, as all large companies (with more than 
250 employees) have an HR department, where $88.9 \%$ of them have 2 or more employees in HR department. None of respondent small companies has an HR department. The size of HR department varies depending on the total number of employees in the company, and increases with the increase of the size of the company- HR departments consisting of 5 or more employees may be found only in large agricultural and food processing foreign-owned companies in this sample.

\section{Analysis and results}

The analysis of data has shown that majority of companies perform most of HRM activities. Thus, it may be claimed that Hypothesis 1 was supported. Analysis of each particular HR activity in surveyed agricultural and food processing companies performed through multinomial logistic regression led to the following results. Regarding HR planning, the analysis has shown that all surveyed companies plan their HR needs. Majority (66.7\%) of companies plan their HR needs both on long-term (most often annually) as well as shortterm, while those remaining make only short-term HR plans. The analysis has shown that the only variable which influenced HR planning process was the number of employees in HR department. Found relationship was statistically significant and positive, meaning that increased number of employees in HR department will result in increased likelihood that a company will make both short-term as well as long-term HR plans (rather than only shortterm plans), (Table 2). Thus, only Hypothesis 5 was supported for this HRM activity.

Table 2. HR planning

\begin{tabular}{|l|c|c|c|c|c|c|}
\hline \multicolumn{2}{|c|}{ HR planning a } & B & Std. Error & Wald & df & Sig \\
\hline $\begin{array}{l}\text { Long-term and } \\
\text { short-term }\end{array}$ & Intercept & $-2,5$ & 1,04 & 5,781 & 1 & 0,016 \\
\hline HR planning & Size of HR dept. & 4,125 & 1,278 & 10,417 & 1 & 0,001 \\
\hline
\end{tabular}

Note: a - the reference category is: 'Only short-term HR planning'.

Source: According to data from Ratković, 2014.

All surveyed agro-food companies recruit job candidates. The analysis has shown that there is an equal number of companies which perform recruitment by themselves and those which outsource this HRM activity, while the performance of this HRM activity depends on the size of the company. The relationship found between these variables was positive and statistically significant (Table 3), suggesting that the increase of the total number of employees leads to increased likelihood that recruitment process will be done in-house, rather than outsourced. Thus, it may be claimed that in terms of recruitment only Hypothesis 2 was supported. 
Table 3. Recruitment

\begin{tabular}{|c|c|c|c|c|c|c|}
\hline \multicolumn{2}{|c|}{ Recruitment $^{\text {a }}$} & B & Std. Error & Wald & Df & Sig. \\
\hline $\begin{array}{l}\text { Performed in } \\
\text { the company }\end{array}$ & Intercept & $-4,289$ & 1,429 & 9,009 & 1 & 0,003 \\
\cline { 2 - 7 } & Company size & 0,022 & 0,008 & 8,528 & 1 & 0,003 \\
\hline
\end{tabular}

Note: a - the reference category is: 'Recruitment outsourced'.

Source: According to data from Ratković, 2014.

Analysis has shown that all surveyed companies perform selection process, $64.3 \%$ of them perform this process by themselves, while only $35.7 \%$ of them outsource this activity. The results of this analysis have confirmed that the decision on the way of performing this activity depends on the size of HR department. This relationship was positive, meaning that more employees in HR department increase the likelihood that the company will perform selection itself (rather than delegate this process to an HR agency). Thus, support was found for Hypothesis 5 for this HRM activity; however, this relationship was not statistically significant.

The results of the survey have shown that majority of companies (78.6\%) organize training programs for their employees: 17 companies organize indoor trainings, while 16 of them outsource this HRM activity. The analysis confirmed that the use of training programs in foreign-owned agricultural and food processing companies in Serbia depends on the size of HR department, where more employees in HR department lead to higher likelihood that training programs will be organized within the company, rather than outsourced. Thus, support was found for Hypothesis 5 for this HRM activity; however, this relationship was not statistically significant.

Performance appraisal was not common in all respondent companies- half of companies formally evaluate performance of their employees (and there was only one company which outsourced this activity). Company size was found to have an impact on the decision of the company to perform this activity itself, or outsource it (statistically significant relationship was found), (Table 4). Thus, Hypothesis 2 was supported for this HRM activity.

Table 4. Performance appraisal

\begin{tabular}{|l|c|c|c|c|c|c|}
\hline \multicolumn{2}{|c|}{ Performance appraisal } & B & Std. Error & Wald & df & Sig. \\
\hline \multirow{2}{*}{$\begin{array}{l}\text { Performed in the } \\
\text { company }\end{array}$} & Intercept & $-2,296$ & 0,742 & 9,582 & 1 & 0,002 \\
\cline { 2 - 7 } & $\begin{array}{c}\text { Size of } \\
\text { company }\end{array}$ & 0,009 & 0,003 & 7,748 & 1 & 0,005 \\
\hline \multirow{2}{*}{ Outsourced } & Intercept & $-3,803$ & 1,484 & 6,565 & 1 & 0,01 \\
\cline { 2 - 7 } & $\begin{array}{c}\text { Size of } \\
\text { company }\end{array}$ & 0,005 & 0,006 & 0,902 & 1 & 0,342 \\
\hline
\end{tabular}

Note: a - the reference category is: 'Performance appraisal does not exist' Source: According to data from Ratković, 2014.

Additionally, support was found for Hypothesis 5, as the number of employees in HR department was found to have an influence on the likelihood that the company will perform formal performance appraisal process, but this relationship was not statistically significant. 
Surveyed agricultural and food processing organizations conduct performance appraisal on annual basis $(81 \%)$ or twice a year (19\%). It was found that the frequency of performance appraisal of employees depends on the number of employees in HR department, where higher number of employees in HR department increases the likelihood that company will formally evaluate performance of their employees more frequently than once a year (the relationship found was negative, but not statistically significant).

Cross-tabulation was used to examine the relationship between different HRM processes. The analysis of data has shown that there is a statistically significant relationship between HR planning and recruitment process performed by surveyed agro-food companies ( $\mathrm{p}=0,000)$, (Table 5). The majority of companies which perform both short-term and long-term HR planning perform recruitment of potential job candidates themselves, while companies which plan their HR needs only on a shortterm mainly outsource recruitment process.

Table 5. Chi-Square Tests (HR planning vs. recruitment)

\begin{tabular}{|l|c|c|c|c|c|}
\hline HR planning vs. recruitment & Value & Df & $\begin{array}{c}\text { Asymp. Sig. } \\
\text { (2-sided) }\end{array}$ & $\begin{array}{c}\text { Exact Sig. } \\
\text { (2-sided) }\end{array}$ & $\begin{array}{c}\text { Exact Sig. } \\
\text { (1-sided) }\end{array}$ \\
\hline Pearson Chi-Square & $15,429^{\text {a }}$ & 1 & 0,000 & & \\
\hline Continuity Correction ${ }^{\mathrm{b}}$ & 12,964 & 1 & 0,000 & & \\
\hline Likelihood Ratio & 17,516 & 1 & 0,000 & & \\
\hline Fisher's Exact Test & & & & 0,000 & 0,000 \\
\hline Linear-by-Linear Association & 15,061 & 1 & 0,000 & & \\
\hline No. of Valid Cases & 42 & & & & \\
\hline
\end{tabular}

Note: a - 0 cells $(0.0 \%)$ have expected count less than 5 . The minimum expected count is 7.00 . b - Computed only for a $2 \times 2$ table.

Source: According to data from Ratković, 2014.

Similar relationship was found between HR planning and performance appraisal process. All companies which perform both short-term and long-term HR planning also have formal performance appraisal of their employees. On the other hand, companies which plan their HR needs only on a short-term mainly do not formally evaluate performance of their employees. This relationship is statistically significant $(p=0,000)$, (Table 6).

Table 6. Chi-Square Tests (HR planning vs. performance appraisal)

\begin{tabular}{|l|c|c|c|}
\hline $\begin{array}{c}\text { HR planning vs. performance } \\
\text { appraisal }\end{array}$ & Value & df & Asymp. Sig. (2-sided) \\
\hline Pearson Chi-Square & $21,000^{\mathrm{a}}$ & 2 & 0,000 \\
\hline Likelihood Ratio & 26,734 & 2 & 0,000 \\
\hline Linear-by-Linear Association & 20,024 & 1 & 0,000 \\
\hline No. of Valid Cases & 42 & & \\
\hline
\end{tabular}

Note: a - 2 cells (33.3\%) have expected count less than 5 . The minimum expected count is 0.33 . Source: According to data from Ratković, 2014. 
Regarding the relationship between recruitment and performance appraisal process in surveyed companies, it may be noticed that the majority of companies which recruit potential job candidates themselves also apply their own performance appraisal process. On the other hand, companies which mainly outsource recruitment process usually do not formally appraise performance of their employees. The relationship found is statistically significant $(\mathrm{p}=0,000)$, (Table 7).

Table 7. Chi-Square Tests (recruitment vs. performance appraisal)

\begin{tabular}{|l|r|c|r|}
\hline \multicolumn{1}{|c|}{ Recruitment vs. performance appraisal } & \multicolumn{1}{c|}{ Value } & Df & Asymp. Sig. (2-sided) \\
\hline Pearson Chi-Square & $18,848 \mathrm{a}$ & 2 & 0,000 \\
\hline Likelihood Ratio & 20,866 & 2 & 0,000 \\
\hline Linear-by-Linear Association & 17,367 & 1 & 0,000 \\
\hline No. of Valid Cases & 42 & & \\
\hline
\end{tabular}

Note: a - 2 cells $(33.3 \%)$ have expected count less than 5 . The minimum expected count is 0.50 . Source: According to data from Ratković, 2014.

\section{Concluding remarks}

This research conducted in 42 foreign-owned agricultural and food processing companies in Serbia intended to examine the degree to which these companies implement key HRM activities (planning, recruitment, selection, training, performance appraisal), and to discover whether they mainly perform these activities by themselves or through outsourcing. The analysis of data confirmed the expectations that the surveyed companies mainly perform most of key HRM activities. The findings have shown that all examined HRM activities are mainly performed in-house, rather than outsourced. A possible explanation may be that surveyed companies originate mainly from developed Western countries where modern methods of HRM are widely applied, and thus implement their knowledge and experience in their subsidiaries in Serbia.

Certain variables (primarily size of company and size of HR department) were found to influence the decision of a particular agro-food company to implement its own HRM processes rather than outsource key HRM activities. As far as HR planning is concerned, which is performed in-house in all surveyed companies, companies with larger HR departments are more committed to HR planning process (i.e. they make both annual HR plans as well as short-term plans), than companies with less staff responsible for HR-relates issues, which due to lack of experience, plan their HR needs only on a short-term basis. Larger foreign-owned agro-food companies operating in Serbia prefer in-house recruiting in order to find qualified job candidates. Since they have more resources and more employees which may be delegated to this process, as well as much more experience in all business processes comparing to small companies, they tend to develop their own specific recruitment methods and techniques and it is thought that they may find the candidates more quickly and efficiently when they perform recruitment in-house. Owning to lack of knowledge and experience smaller companies covered by this survey do not apply performance appraisal of their employees. Unlike them, 
larger companies were found to implement formal performance appraisal, as one of crucial HRM activities aimed at motivating employees and improving their performance on a longterm basis.

The analysis has found that HR planning, recruitment and performance appraisal are usually interdependent processes in foreign-owned agricultural and food processing companies in Serbia. This may lead to the conclusion that those companies which are extensively committed to HR planning (companies which plan their HR needs not only ad hoc, but also make long-term plans), prefer in-house recruitment and formal performance appraisal. On the other hand, companies which usually do not plan their HR needs on a long-term, usually outsource recruitment process and don't have formal performance appraisal of their employees.

Having in mind limited literature and empirical research dealing with the implementation of different HRM practices in agricultural and food processing companies (in general and in Serbia), the findings of this study may be useful both for foreign agro-food companies which plan to enter specific Serbian market, as well as local companies which still lack experience and knowledge, and tend to learn from more experienced foreign companies (mainly multinational companies) and often copy their methods of performing key processes.

\section{Literature}

1. Baptista, R. D. (2012): Technological Transition and the New Skills Required by the Agribusiness Sector, International Food and Agribusiness Management Review, vol. 15, spec. issue A, pp. 105-109, available at http://ifama.i4adev.com/files/\%252819\%25 29\%2520Baptista4.pdf

2. Barnard, F., Akridge, J., Dooley, F., Foltz, J. (2012): Agribusiness management (4 $4^{\text {th }}$ ed.), Routledge, New York, USA.

3. Barney, J. B. (1991): Firm Resources and Sustained Competitive Advantage, Journal of Management, vol. 17, no. 1, pp. 99-120.

4. Berde, C. (2006): Human resource management in Hungarian agriculture, Jahrbuch der Österreichischen Gesellschaft für Agrarökonomie, no. 15, pp. 157-164, available at: http://oega.boku.ac.at/fileadmin/user upload/Tagung/2005/05 Berde.pdf

5. Bitsch, V. (2009): Personnel Management Research in Agribusiness, $19^{\text {th }}$ Annual World Forum and Symposium of the International Food and Agribusiness Management Association, Budapest, June 20-23, available at:www.ifama.org/events/conferences/2009/ cmsdocs $/ 1067$ paper.pdf

6. Brewster, C., Sparrow, P., Vernon, G. (2007): International Human Resource Management ( $2^{\text {nd }}$ ed.), CIPD, London, UK.

7. Bugar, D., Papić Blagojević, N. (2009): Konkurentnost agrobiznis sektora Srbije u funkciji poboljšanja spoljnotrgovinske razmene, Škola biznisa naučnostručni časopis, no. 3, pp. 43-48.

8. Contò, F., Fiore, M., La Sala, P., Papapietro, P. (2012): The Role of Education, Knowledge and Human Resources for the Agricultural Development in the Perspective of New Cap: An Hypothesis of Change in Basilicata, Applied Studies in Agribusiness 
and Commerce, no. 1-2, pp.123-129.

9. Cromer, D. (2008): State of HR Management in Serbia, Cromergroup, University of Liverpool (eds), UK.

10. Dessler, G. (2011): Human Resource Management (12 ${ }^{\text {th }}$ ed.), Prentice Hall, Boston, USA.

11. Grozdanić, R. (2013): Agribusiness and Agro-Industrial Strategies, Policies and Priorities for Achieving Higher Competitiveness, Employability and Sustainability in the Western Balkans Region, Friedrich-Ebert-Stiftung, Regional Project for Labour Relations and Social Dialogue in South East Europe, Belgrade, Serbia.

12. Mihailović, B., Cvijanović, D., Paraušić, V. (2013): Analiza performansi primarne poljoprivredne proizvodnje i prehrambene industrije Srbije, Agroznanje, vol. 14, no. 1, pp. 77-85.

13. Ministry of Agriculture, Forestry and Water Management of the Republic of Serbia (2014): Strategija poljoprivrede i ruralnog razvoja Republike Srbije za period 20142024. godine, Official Gazette of the Republic of Serbia, no. 85/2014, Belgrade, available at http://uap.gov.rs/wp-content/themes/uap/STRATEGIJA\%2020142020\%20.pdf

14. Morgan, J. M., Reynolds, C. M., Nelson, T. J., Johanningmeier, A. R., Griffin, M., Andrade, P. (2004): Tales from the Fields: Sources of Employee Identification in Agribusiness, Management Communication Quarterly, vol. 17, no. 3, pp. 360-395.

15. Mugera, A. W. (2012): Sustained Competitive Advantage in Agribusiness: Applying the Resource-Based Theory to Human Resources, International Food and Agribusiness Management Review, vol. 15, no. 4, pp. 27-48, available at: http://ageconsearch.umn. edu/bitstream/138318/2/20120017 Formatted.pdf

16. Mugera, A. W. (2010): Does Good Personnel Management Practices give Agribusiness Firms a Competitive Advantage?, Annual National Conference of the Australia Agricultural \& Resources Economics Society, February 10-12, Adelaide, South Australia.

17. Noel, J., Qenani, E. (2013): New Age, New Learners, New Skills: What Skills Do Agribusiness Graduates Need to Succeed in the Knowledge Economy?, International Food and Agribusiness Management Review, vol. 16, no. 3, pp. 17-36.

18. Ratković, T. (2014): Anketa o HR procedurama $i$ praksama u filijalama multinacionalnih kompanija u Srbiji, interna dokumentacija (upitnici), Fakultet organizacionih nauka, Univerzitet u Beogradu, Beograd.

19. Siva Rama Krishna, K., Ramesh, K., Gangadhara Rao, M. (1995): Human Resource Management in Agriculture, Discovering Publishing House, New Delhi, India.

20.Svetlik, I., Barišić, A. F., Kohont, A., Petković, M., Aleksić Mirić, A., Slavić, A., Vaupot, Z., Poór, J. (2010): Human Resource Management in the Countries of the Former Yugoslavia, Review of International Comparative Management, vol. 11, no. 5, pp. 807-833.

21. Vapa Tankosić, J., Stojsavljević, M. (2012): New perspectives for economic growth: Agribusiness as Serbia's way out of financial crisis, in: European Integration Process in Western Balkan Countries, Teixeira, P., Portugal Duarte, A., Redžepagić, S., Erić, D., Andrejević, S. (Eds.), Faculty of Economics of the University of Coimbra, Coimbra, Portugal, pp. 726-740. 
22. Venclová, K., Königová, M., Fejfar, J. (2013): Current State of the Employee Performance Appraisal System in Agricultural Organizations in the Czech Republic, Acta Universitatis Agriculturae et Silviculturae Mendelianae Brunensis, LXI, no. 4, pp. 1183-1189.

23. Wilk, E., Fensterseifer, J. (2003): Towards A National Agribusiness System: A Conceptual Framework, International Food and Agribusiness Management Review, vol. 6, no. 2, pp. 99-110.

\section{MENADŽMENT LJUDSKIH RESURSA U POLJOPRIVREDNIM I PREHRAMBENIM KOMPANIJAMA U STRANOM VLASNIŠTVU U SRBIJI}

\section{Tatjana Ratković}

Rezime

Cilj ovog rada je da pokuša da ispita u kojoj meri poljoprivredne i prehrambene kompanije u stranom vlasništvu u Srbiji primenjuju ključne procese menadžmenta ljudskih resursa, da utvrdi da li ove procese sprovodi kompanija ili ih povereva specijalizovanim agencijama, kao $i$ da identifikuje varijable koje imaju uticaj na način sprovođenja ovih procesa u kompanijama. Istraživanjesprovedeno u 42 kompanijepotvrdilojeočekivanja da analizirane kompanije sprovode većinu ključnih aktivnosti menadžmenta ljudskih resursa. U zaključku rada navodi se da se sve analizirane aktivnosti uglavnom sprovode u kompanijama (tj. kompanije ređe angažuju agencije specijalizovane za obavljanje tih poslova), dok način na koji kompanija sprovodi ključne procese upravljanja ljudskim resursima najčešće zavisi od veličine kompanije $i$ veličine odeljenja za ljudske resurse, što ukazuje na to da strane kompanije koje posluju u ovom sektoru u Srbiji moraju uzeti u obzir ove varijable prilikom donošenja odluke o tome da li da same sprovode ključne aktivnosti menadžmenta ljudskih resursa ili da njihovo sprovođenje povere specijalizovanim agencijama.

Ključne reči: menadžment ljudskih resursa, poljoprivreda, prehrambena industrija, regrutovanje, vrednovanje učinka zaposlenih.

2 Dr Tatjana Ratković, Asistent, Fakultet organizacionih nauka, Univerzitet u Beogradu, Jove Ilića 154, 11000 Beograd, Srbija, Telefon: +381 113950 898, E-mail: tatjana.ratkovic@,fon.bg.ac.rs 